\title{
The role of editors or a team of professional editors should be fulfilled for mitigating the COVID-19 pandemic
}

\author{
yoshiyasu takefuji ${ }^{1}$ \\ ${ }^{1}$ Affiliation not available
}

October 5, 2020

\begin{abstract}
The role of editors or a team of editors has two important tasks: deciding a paper for review or not, and writing editorials for disseminating messages to the world.
\end{abstract}

\section{ABSTRACT}

The role of editors or a team of editors has two important tasks: deciding a paper for review or not, and writing editorials for disseminating messages to the world.

\section{TEXT}

SARS-CoV-2 was named after SARS by WHO on Feb. 112020 (1). This virus naming means that SARS$\mathrm{CoV}-2$ is very similar to SARS-COV. Both SARS-CoV and SARS-CoV-2 use human ACE2 as entry receptor and human proteases as entry activators (2).

After Feb. 11 2020, as soon as possible we should have seen the disseminated editorial messages to the world for mitigating the COVID-19 pandemic on the following facts which are learned lessons from SARS:

1. Airborne precaution against COVID-19 $(3,4,5,6)$,

2. Banning the air travel (7),

3. COVID-19 is an asymptomatic infection disease $(8,9,10,11,12,13)$,

4. Good ventilation against COVID-19 (3).

The role of editors or a team of professional editors should be fulfilled for mitigating the COVID-19 pandemic. Remember that there is still no coronavirus vaccine for SARS (17 years ago) and MERS (7 year ago) despite dozens of attempts to develop them.

\section{References:}

1.https://www.who.int/emergencies/diseases/novel-coronavirus-2019/technical-guidance/naming-thecoronavirus-disease-(covid-2019)-and-the-virus-that-causes-it

2. Rossi, G.A., Sacco, O., Mancino, E. et al. Differences and similarities between SARS-CoV and SARSCoV-2: spike receptor-binding domain recognition and host cell infection with support of cellular serine proteases. Infection (2020).

https://doi.org/10.1007/s15010-020-01486-5 
3. N Engl J Med 2004; 350:1731-1739 DOI: 10.1056/NEJMoa032867

4. Timothy F. Booth et al., Detection of Airborne Severe Acute Respiratory Syndrome (SARS) Coronavirus and Environmental Contamination in SARS Outbreak Units, The Journal of Infectious Diseases, Volume 191, Issue 9, 1 May 2005, Pages 1472-1477,https://doi.org/10.1086/429634

5. Xiao S, Li Y, Wong T-w, Hui DSC (2017) Role of fomites in SARS transmission during the largest hospital outbreak in Hong Kong.

PLoS ONE 12(7): e0181558.https://doi.org/10.1371/journal.pone.0181558

6. Hagbom, M., Nordgren, J., Nybom, R. et al. Ionizing air affects influenza virus infectivity and prevents airborne-transmission. Sci Rep 5, 11431 (2015).

https://doi.org/10.1038/srep11431

7. https://www.who.int/health-topics/severe-acute-respiratory-syndrome

8. Lee HK, Tso EY, Chau TN, et al. Asymptomatic Severe Acute Respiratory Syndrome-associated Coronavirus Infection.

Emerging Infectious Diseases. 2003;9(11):1491-1492. doi:10.3201/eid0911.030401.

9. Wilder-Smith A., Teleman M.D., Heng B.H., Earnest A., Ling A.E. Asymptomatic SARS coronavirus infection among healthcare workers, Singapore.

Emerg Infect Dis. 2005;11:1142-1145.

10. Rainer $\mathrm{TH}$ et al. The spectrum of severe acute respiratory syndrome-associated coronavirus infection.

Ann Intern Med 2004 Apr 20; 140:614-9.

11. Xiao-yan Che et al., A Patient with Asymptomatic Severe Acute Respiratory Syndrome (SARS) and Antigenemia from the 2003-2004 Community Outbreak of SARS in Guangzhou, China, Clinical Infectious Diseases, Volume 43, Issue 1, 1 July 2006, Pages e1-e5,https://doi.org/10.1086/504943

12. Consensus document on the epidemiology of severe acute respiratory syndrome (SARS), WHO,https://www.who.int/csr/sars/WHOconsensus.pdf?ua=1

13. Cherry, J., Krogstad, P. SARS: The First Pandemic of the 21st Century. Pediatr Res 56, 1-5 (2004).https://doi.org/10.1203/01.PDR.0000129184.87042.FC 